\title{
APLIKASI METODE GEOLISTRIK DALAM SURVEY POTENSI HIDROTHERMAL (STUDI KASUS: SEKITAR SUMBER AIR PANAS KASINAN PESANGGRAHAN BATU)
}

\author{
Oleh:
}

Ika Yulia Sulistyarini ${ }^{1}, \operatorname{Irjan}^{2}$

\begin{abstract}
ABSTRAK: Panas bumi merupakan salah satu sumber daya alam yang banyak memberikan manfaat untuk manusia sehingga perlu adanya penelitian untuk mengeksplorasi keberadaan air panas di daerah sekitar sumber air panas Kasinan Pesanggrahan Kota Batu. Penelitian ini bertujuan untuk mengetahui besar potensi air panas (hydrothermal) di daerah penelitian. Metode yang digunakan pada penelitian ini adalah metode Geolistrik Resistivitas konfigurasi Wenner Sounding and Mapping dan pengukuran dilakukan dengan menggunakan resistivitymeter MGG 1260.

Hasil penelitian menunjukkan lapisan penyusun bawah permukaan pada lintasan $\mathrm{B}$ dan $\mathrm{C}$ tidak kontinu dan didominasi oleh lapisan yang tidak memiliki sifat pembawa air panas yang berupa batuan lava dan campuran batuan lava dengan andesit yang menunjukkan kemas tertutup dan porositas batuan jelek. Potensi air panas masih kecil dan diduga air panas yang muncul ke permukaan berasal dari aliran air panas dari arah songgoriti-cangar. Air panas tersebut muncul ke permukaan diduga karena adanya rekahan batuan di bawah permukaan.
\end{abstract}

Kata Kunci : Air Panas (Hidrothermal), Geolistrik Resistivitas Konfigurasi Wenner, Potensi air panas.

\section{PENDAHULUAN}

Daerah sumber air panas Kasinan Desa Pesanggrahan Kecamatan Batu terletak pada ketinggian $\pm 1175 \mathrm{~m}$, di kaki Gunung Panderman yang merupakan rangkaian gunung api padam akan tetapi masih memiliki potensi di dalamnya karena daerah ini berada di sekitar deretan gunung api Arjuno-Wellirang yang masih terdapat aktivitas didalamnya meskipun sudah tidak pernah meletus. Menurut beberapa warga, di daerah Kasinan tersebut memiliki potensi geothermal. Hal ini terbukti dengan munculnya sumber air panas di permukaan yang dapat memberikan suatu indikasi adanya aktivitas hidrothermal panas bumi di bawah permukaan.

Sumber panas bumi berasal dari aktivitas gunung api yang berupa magma. Adanya aktivitas gunung api banyak memberikan manfaat bagi manusia dimana salah satu manfaat tersebut adalah adanya potensi geothermal. Manfaat air panas selain untuk keperluan sehari-hari seperti mandi dan pariwisawata, juga bermanfaat sebagai energi pembangkit listrik tenaga panas bumi (PLTPB) dan juga sebagai energi alternatif pengganti minyak bumi dan gas bumi serta batubara yang jumlahnya hampir habis. Pembangkit listrik tenaga panas bumi (PLTPB) pada prinsipnya sama seperti pembangkit listrik tenaga uap (PLTU), hanya pada PLTU uap dibuat di permukaan menggunakan

1,2 Jurusan Fisika UIN Maulana Malik Ibrahim Malang

Created with 
boiler, sedangkan pada PLTPB uap berasal dari reservoir panas bumi. Untuk mengetahui besarnya potensi air panas tersebut, maka perlu diadakan penelitian di sekitar sumber air panas Kasinan mengingat daerah itu telah dilirik oleh pihak Pemerintah Kota Batu dan juga masih belum terpublikasikan dalam artian hanya masyarakat sekitar yang mengetahui akan adanya sumber air panas tersebut. Melalui penelitian ini diharapkan bisa di ketahui seberapa besar potensi air panas yang dimiliki.

\section{KAJIAN TEORI}

Secara bahasa, kata geothermal terbentuk dari dua kata yaitu geo yang berarti bumi dan thermal yang artinya panas. Jadi istilah geothermal diartikan sebagai panas bumi. Geothermal juga dapat diartikan sebagai panas bumi yang terbentuk secara alami di bawah permukaan bumi.

Panas bumi secara umum dapat diartikan sebagai jumlah kandungan panas yang tersimpan dalam bumi dan membentuk sistem panas bumi yang telah ada sejak bumi terbentuk. Sistem panas bumi tersebut mencakup sistem hidrothermal yang merupakan sistem tata air, proses pemanasan dan kondisi sistem dimana air yang terpanasi terkumpul sehingga sistem panas bumi mempunyai persyaratan seperti harus tersedianya air, batuan pemanas, batuan sarang, dan batuan penutup (Alzwar, Samodra, Tarigan, 1987).

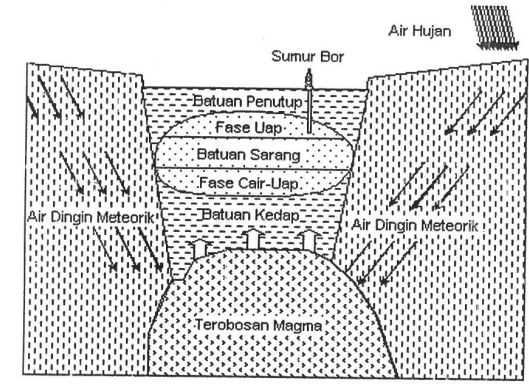

Gambar 1. Sistem panas bumi (Alzwar, Samodra, Tarigan, 1987)

Metode geolistrik resistivitas bekerja karena pengukuran beda potensial pada titiktitik di permukaan bumi yang diproduksi dengan langsung mengalirkan arus ke bawah permukaan. Hal ini bermanfaat untuk menentukan distribusi resistivitas di bawah permukaan dan kemudian digunakan untuk interpretasi material-material yang ada di dalam bumi.

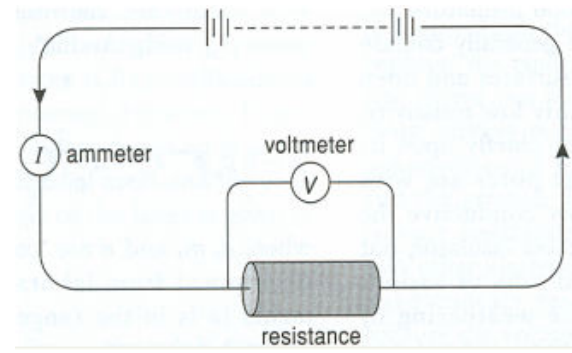

Gambar 2. Rangkaian listrik sederhana (Burger, 1992).

Hambatan dari resistor sebagaimana yang diilustrasikan pada gambar di atas bergantung pada panjang kolom pipa dan juga material dasar yang menyusunnya, yang 
kita namakan resistivitas dan dinotasikan dalam $\rho$, sehingga kita dapat menyebutkan bahwa

$$
\rho=R \frac{A}{L}
$$

Satuan dari resistivitas adalah hambatan dikalikan panjang yang dinotasikan dalam ohm meter. Resistivitas merpakan kebalikan dari konduktivitas, begitu juga sebaliknya (Burger, 1992)

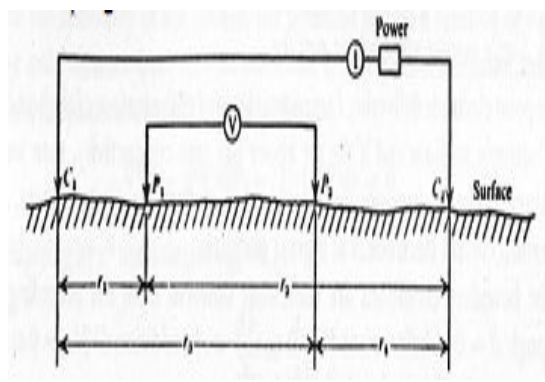

Gambar 3. Dua elektroda arus dan dua elektroda potensial pada permukaan tanah homogen isotropik pada resisitivitas $\rho$ (Telford,1990).

Ketika arus diinjeksikan pada permukaan tanah melalui dua elektroda arus $\mathrm{C} 1$ dan C2, maka beda potensial yang terjadi dari gambar 3, pada elektroda P1 dan P2 adalah:

$$
\Delta V=\frac{I f}{2 \pi}\left\{\left(\frac{1}{r_{1}}-\frac{1}{r_{2}}\right)-\left(\frac{1}{r_{\mathrm{g}}}-\frac{1}{r_{4}}\right)\right\}
$$

Kemudian, untuk mengukur nilai resistivitas di lapangan digunakan persamaan:

$$
\rho=k\left(\frac{\Delta V}{l}\right)
$$

Namun karena sifat bumi yang pada umumnya berlapis (terutama di dekat permukaan) perandaian bahwa mediumnya adalah homogen tidak terpenuhi. Biasanya resistivitas yang terukur tersebut dikenal sebagai resistivitas semu atau apparent resistivity, yang biasa dituliskan dengan simbol $\rho_{\alpha}$.

Besar resistivitas semu dipengaruhi oleh konfigurasi elektroda yang digunakan, hal ini disebabkan karena setiap konfigurasi elektroda memiliki faktor $k$ yang berbeda berdasar susunan dari elektrodanya. Konfigurasi wenner mempunyai ciri jarak antar elektroda adalah sama, sehingga memberikan faktor geometri $k=2 \pi a$, yang diperoleh dari

$$
k=2 \pi\left(\frac{1}{A M}-\frac{1}{M E}-\frac{1}{A N}+\frac{\vdots}{N E}\right)
$$

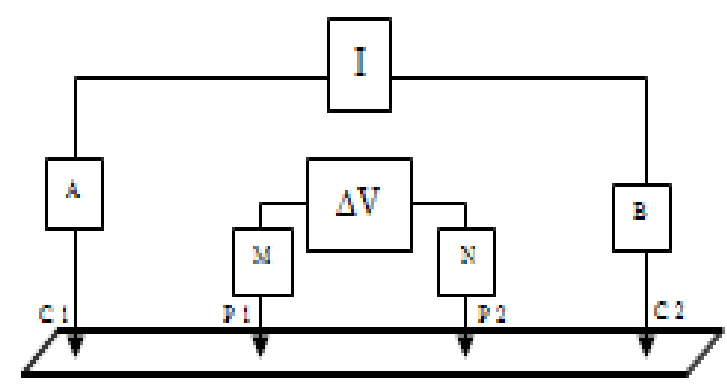

Gambar 4. Konfigurasi wenner (Burger, 1992) 


\section{METODE PENELITIAN \\ Waktu dan Tempat Penelitian}

Penelitian ini dilakukan pada bulan Mei 2011 dan pengambilan data dilakukan disekitar sumber air panas Kasinan Pesanggrahan Batu. Lokasi tersebut berada pada posisi 07052'804"-07052'837'LS dan pada posisi 112029'794"-112029'833'BT, pada ketinggian antara 1108 - 1134 meter diatas permukaan laut

\section{Alat Dan Bahan}

Peralatan penunjang dalam penelitian ini meliputi resistivitymeter MGG 1260, GPS (Global Positioning System), peta geologi dan hidrogeologi daerah penelitian, meteran, alat tulis dan clipboard, palu, seperangkat laptop dengan OS Microsoft Windows XP.

\section{Akuisisi Data}

Pengukuran metode geolistrik konfigurasi wenner sounding and mapping, dilakukan dengan menginjeksikan arus melalui dua elektroda arus dan mengukur beda potensial yang dihasilkan dari dua buah elektroda potensial. Perlu diperhatikan dalam perpindahan dan pemasangan elektroda harus sesuai dengan konfigurasi yang digunakan dan dibuat sedemikian rupa agar dapat mempermudah dalam akuisisi data. Dimana penempatan elektroda dan kedalaman elektroda (arus dan potensial) harus benar (lebih kurang $15 \mathrm{~cm}$ ) tertancap di dalam bumi supaya di dapatkan data yang akurat. Selain itu kabel arus dan kabel potensial harus terpasang dengan benar. Data yang terukur adalah kuat arus, beda potensial, dan jarak spasi antar elektroda. Sedangkan data topografi yang didapatkan dari GPS berupa posisi lintang selatan, bujur timur, dan ketinggian pada tiap titik datum.

\section{Processing Data}

Data yang didapatkan dari pengukuran wenner sounding kemudian diolah dengan software IP2win, dengan memasukkan besar nilai arus (I) dan nilai beda potensial $(\Delta \mathrm{V})$ serta jarak spasi elektroda (a) ke dalam software IP2win dan hasilnya berupa tampilan grafik dan nilai resistivitas batuan ( $\rho$ ) lapisan di bawah permukaan tanah secara vertikal.

Pertama yang harus dilakukan adalah menghitung faktor geometri $\mathrm{k}$ untuk konfigurasi wenner dengan persamaan $k=2 \pi a$ kemudian menghitung nilai resistivitas batuan, dimana nilai resistivitas yang didapatkan ini merupakan nilai resistivitas semu atau apparent resistivity. Karena batuan yang berada di bawah permukaan bumi sebenarnya terdiri dari banyak lapisan dengan nilai resistivitas yang berbeda, sehingga bukan resisstivitas sebenarnya yang didapatkan. Untuk mengetahui nilai resisitivitas yang sebenarnya dari masing-masing lapisan. Maka proses yang ditempuh adalah dengan melakukan proses inversi hingga didapatkan kesalahan (error) paling kecil (biasanya kurang dari 10\%).

Hasil pengolahan data dengan software IP2win adalah dalam bentuk kurva 2 dimensi dan dalam bentuk tabel. Grafik terdiri dari kurva yang berwarna hitam, biru dan merah. Kurva biru merepresentasikan ketebalan dan batas lapisan pada titik sounding, 
kurva merah merupakan kurva standart atau kurva acuan, dan kurva hitam merupakan kurva data penelitian.

Sedangkan pada hasil pengukuran menggunakan wenner mapping, diolah menggunakan software Res2dinv. Perlu diketahui bahwa data yang telah diperoleh tidak dapat langsung dianalisa menggunakan software Res2dinv versi $3.53 \mathrm{~g}$ sebelum ditentukan terlebih dahulu besarnya faktor geometri $(k)$ pada jarak spasi antar elektroda masing-masing. Setelah nilai $k$ didapat, tahap selanjutnya adalah menentukan nilai resistivitas semu $\left(\rho_{a}\right)$. Resistivitas semu $\left(\rho_{a}\right)$ diperoleh dengan menggunakan rumus yang telah ditetapkan. Selanjutnya, semua data hasil pengukuran diolah menggunakan software Microsoft Office Exel. Besarnya nilai resistivitas semu tersebut kemudian diolah menggunakan software Res2dinv versi $3.53 \mathrm{~g}$. Namun sebelum diolah dengan software Res2dinv versi $3.53 \mathrm{~g}$, data-data tersebut terlebih dahulu harus dirubah kedalam format extensi.DAT melalui software surfer 8 .

Setelah tahapan diatas, data dalam format extensi .DAT akan menjadi input pada software Res2dinv versi 3.53g. Lalu dilakukan inversi data hingga diperoleh error minimum. Hasil inversi ditampilkan dalam bentuk peta penampang (pseudosection) bawah permukaan. Melalui software Res2Dinv ver $3.53 g$, dapat diketahui dimensi dan skala tingkat resistivitas $(\rho)$, sehingga lapisan bawah permukaan dapat diduga struktur lapisannya dan batuan penyusunnya. Secara horizontal penyebaran air panas diketahui melalui kontinuitas nilai resistivitas yang sama, sehingga ketebalan dan kedalaman serta arah penyebarannya dapat diketahui.

\section{Interpretasi Data}

Interpretasi adalah langkah terakhir yang harus dilakukan pada penelitian ini, interpretasi diawali dengan pemisahan lapisan-lapisan batuan sesuai dengan nilai resistivitasnya. Dari hasil pemisahan lapisan-lapisan batuan ini, kemudian dilanjutkan dengan mengkorelasikan data resistivitas dari sumur loging yang terindikasi memiliki lapisan yang mengandung air panas terhadap persebaran air panas melalui hasil pemetaan resistivitas mapping. Interpretasi yang dilakukan harus didukung oleh peta geologi dan hidrogeologi daerah penelitian. Selain itu interpretasi dilakukan dengan asumsi: (1) dibawah permukaan terdapat sejumlah lapisan batuan dengan ketebalan terbatas, dan (2) setiap lapisan batuan mempunyai sifat homogen dan secara kelistrikan bersifat isotropik (diukur dari berbagai arah akan memberikan harga yang sama).

Dalam metode geolistrik resistivitas harga-harga tahanan jenis dipengaruhi oleh : (1) komposisi kimiawi dari butiran penyusun dan komposisi dari semen pada batuan, (2) ukuran dari fragmen dan jumlahnya, semakin besar fragmennya dan semakin banyak jumlahnya umumnya harga tahanan jenisnya semakin besar, (3) ada tidaknya fluida yang mengisi pori batuan. Bila pori tidak mengandung fluida atau dalam keadaan kering akan memberikan harga tahanan jenis yang lebih tinggi.

\section{HASIL DAN PEMBAHASAN}

\section{Wenner sounding}

Pengukuran wenner sounding dilakukan pada titik sumber air panas mengikuti lintasan A dengan panjang lintasan maksimum 16 meter yang terbentang dalam jurus

\section{Created with}


timur-barat. Lokasi titik sounding berada pada posisi $07^{\circ} 52^{\prime} 816^{\prime \prime} \mathrm{LS}$ dan $112^{\circ} 29^{\prime} 822^{\prime \prime}$ BT dengan ketinggian 1108 meter.

Hasil pengolahan data geolistrik resistivitas wenner sounding yang dilakukan dengan metode pencocokan kurva (curve matching) adalah berupa model perlapisan bumi di bawah permukaan titik datum yang ditunjukkan pada gambar berikut:

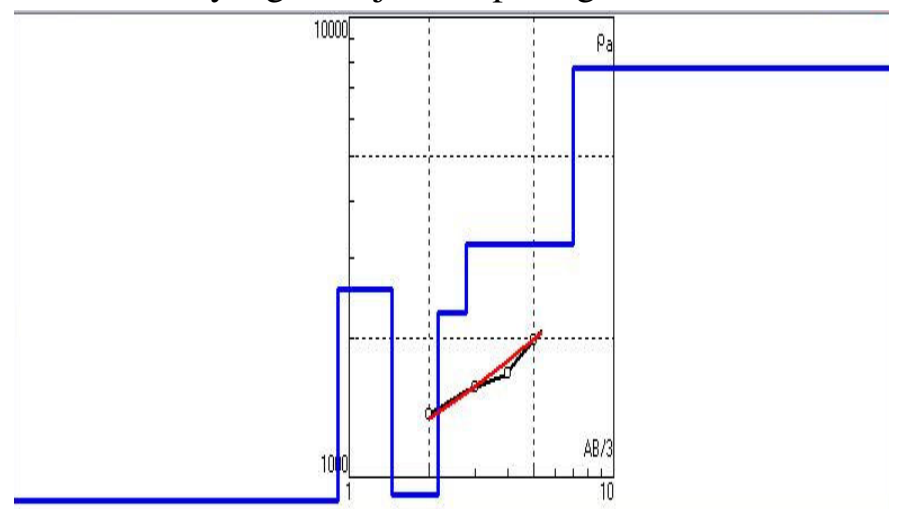

Gambar 1. Pencocokan kurva (curve matching) dan inversi model pelapisan bumi titik sumber

Teknik interpretasi yang digunakan untuk mendapatkan gambaran model perlapisan bumi dibawah permukaan dilakukan dengan cara memplot data dan mencocokkan kurva data hasil pengukuran dengan kurva standart. Metode ini secara prinsip berpedoman pada pencarian nilai error minimum.

Dengan menerapkan metode tersebut akhirnya diperoleh jumlah lapisan bumi sebanyak 6 lapisan dengan kedalaman maksimum adalah 7 meter dan nilai error sebesar 2,86\%. Hasil inversi ini menghasilkan penampang satu dimensi disepanjang dinding sumur dengan nilai-nilai resistivitas yang mendekati keadaan lithologi sebenarnya, ketebalan dan kedalaman untuk masing-masing lapisan dapat dilihat pada tabel berikut:

Tabel 4.1 Hasil interpretasi jumlah lapisan pada titik datum

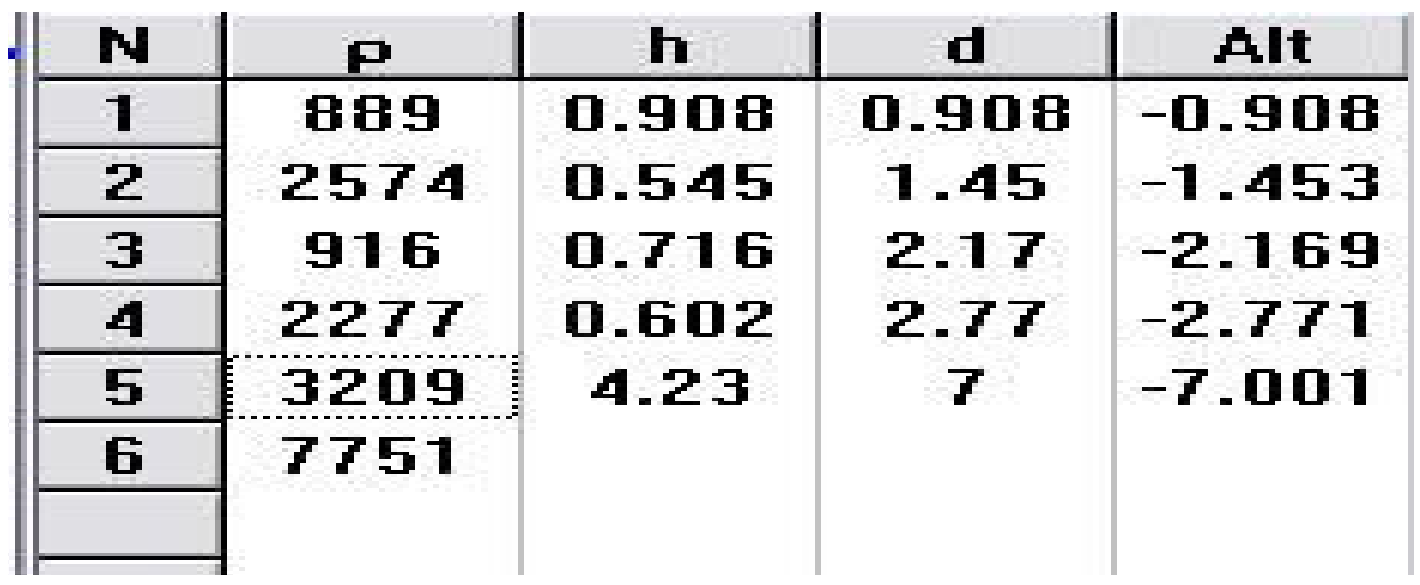

Dari nilai-nilai resistivitas tersebut dapat diduga lithologi batuan penyusunnya setelah dikorelasikan dengan peta geologi setempat. Secara rinci perlapisan yang bersesuaian dengan dugaan lithologi batuan penyusunnya dapat dilihat sebagai berikut: 
Tabel 2. Interpretasi lithologi titik datum

\begin{tabular}{|c|c|c|c|l|}
\hline No & $\begin{array}{c}\text { Kedalaman } \\
(\mathrm{m})\end{array}$ & $\begin{array}{c}\text { Ketebalan } \\
(\mathrm{m})\end{array}$ & $\begin{array}{c}\text { Tahanan Jenis } \\
(\Omega \mathrm{m})\end{array}$ & \multicolumn{1}{|c|}{ Lithologi } \\
\hline 1 & 0,908 & 0,908 & 889 & Breksi vulkanik \\
\hline 2 & 1,45 & 0,545 & 2574 & Batuan lava \\
\hline 3 & 2,17 & 0,716 & 916 & Breksi vulkanik \\
\hline 4 & 2,77 & 0,602 & 2277 & Batuan lava \\
\hline 5 & 7 & 4,23 & 3209 & $\begin{array}{l}\text { Campuran batuan lava } \\
+ \text { andesit }\end{array}$ \\
\hline 6 & - & - & 7751 & \begin{tabular}{l} 
Tak terdefinisi \\
\hline
\end{tabular} \\
\hline
\end{tabular}

Titik sumber

Elevasi : 1108 meter

07'52'816' LS

$112^{\circ} 29^{\prime} 822^{\prime \prime} \mathrm{BT}$

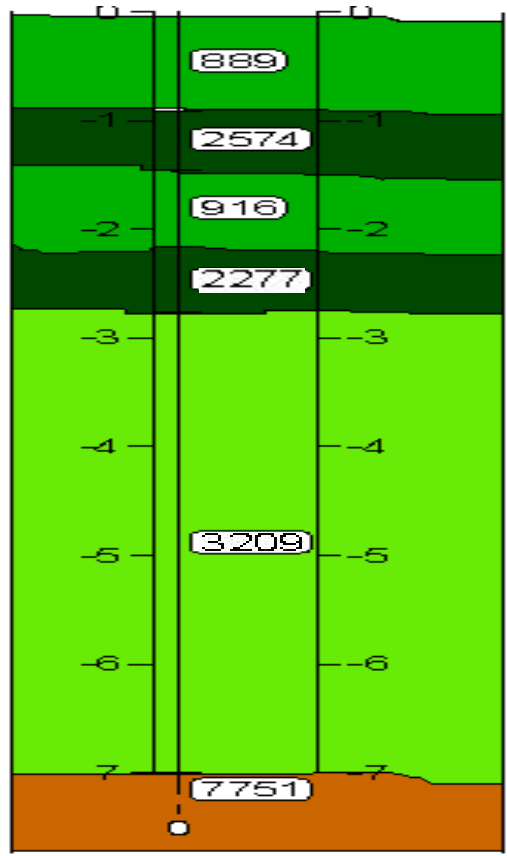

Gambar 2. Lithologi bawah permukaan titik sumber

Keterangan:

$\square$ : lapisan dengan nilai resistivitas $100-1000$ ohm meter

— lapisan dengan nilai resistivitas $2000-3000 \mathrm{ohm}$ meter

$\square$ : lapisan dengan nilai resistivitas $>3000$ ohm meter

$\square$ : lapisan dengan nilai resistivitas $>7000$ ohm meter 


\section{Wenner mapping}

Pengambilan data pada konfigurasi ini terdiri dari dua lintasan yaitu lintasan B (panjang lintasan 40 meter) dan lintasan $\mathrm{C}$ (panjang lintasan 30 meter). Untuk lintasan $\mathrm{B}$ dengan panjang lintasan 40 meter dilakukan pengukuran mulai dari arah utara sumber $( \pm 6$ meter) kearah selatan, sedangkan untuk lintasan $\mathrm{C}$ dengan panjang lintasan 30 meter dilakukan pengukuran mulai dari arah timur laut ke barat daya.

Berdasarkan hasil interpretasi kualitatif diatas bahwa pada lintasan B terdapat berbagai macam batuan hasil endapan pelapukan batuan beku. Namun pada interpretasi kualitatif ini yang akan dibahas adalah formasi batuan yang membawa sifat air panas (hidrothermal) yang terdapat sepanjang lintasan tersebut. Setelah dikorelasikan dengan data geologi diduga bahwa penampang bawah permukaan lintasan B terdiri atas breksi gunungapi, batuan lava, aglomerat dan tufa (tabel resistivitas batuan oleh Suyono, 1978).

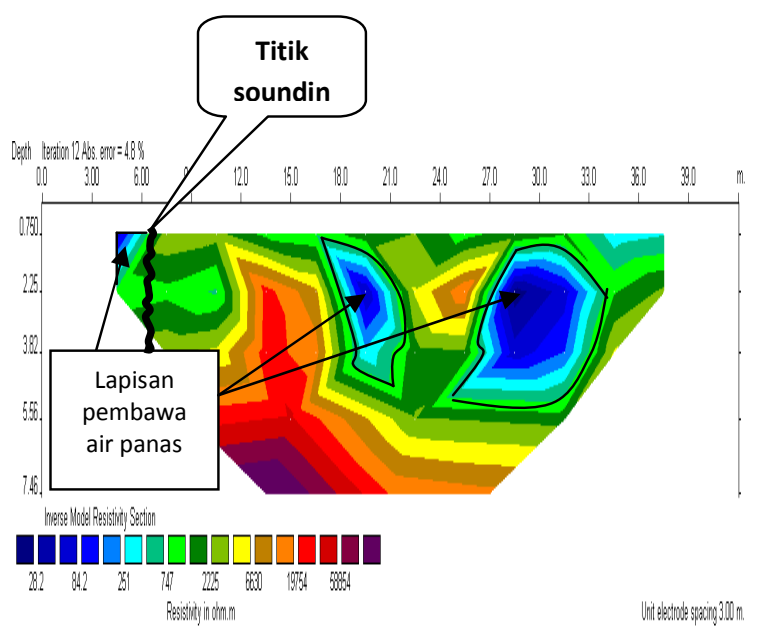

Gambar 3. Lapisan pembawa air panas lintasan B

Untuk lintasan B, penampang anomali resistivitas yang diduga sebagai pembawa air panas yaitu lapisan yang di interpretasikan dengan warna biru (baik biru tua maupun biru cerah). Lapisan dengan warna biru tua tersebut (resistivitas batuan sebesar 28,2 ohm meter) diduga didominasi oleh batuan tufa gunungapi yang berada pada interval resistivitas sebesar 20-200 ohm meter (tabel batuan oleh Suyono, 1978).Batuan tufa gunungapi berukuran pasir halus-lapili dengan ketebalan lapisan yang bervariasi dari 0,5 $\mathrm{cm}-2 \mathrm{~m}$, terpilah sedang, batuan sedikit kompak, dan sangat poros, sedangkan warna biru dengan nilai resistivitas sebesar $84,2 \mathrm{ohm}$ meter diduga juga merupakan tufa gunungapi (tabel resistivitas batuan oleh Suyono, 1978). Selanjutnya lapisan dengan warna biru cerah dengan nilai resistivitas sebesar $251 \mathrm{ohm}$ meter diinterpretasikan sebagai aglomerat yang berada pada interval resistivitas 100-500 ohm meter (tabel resistivitas batuan oleh Suyono, 1978). Batuan ini tidak kompak, berwarna kelabu-coklat kemerahan, berukuran pasir sangat kasar-bom, berkomponen pecahan batuan, mineral hitam, obsidian dan kaca gunungapi, dalam masadasar tuf pasiran dan abuan. Kemudian warna biru kehijauan diinterpretasikan sebagai breksi vulkanik dengan resistivitas batuan sebesar 
747 ohm meter (tabel resistivitas batuan oleh Suyono, 1978). Secara fisik batuan ini agak kompak, berwarna coklat keabu-abuan, masif, fragmen batuan tersusun oleh andesit, porfiri, batuapung, mineral terang dan kaca gunungapi, berbutir kasar-bom dengan bentuk menyudut tanggung-membundar, kemas terbuka dan kesarangan pada batuan cukup baik. Selanjutnya, lapisan dengan warna hijau, hijau tua, kuning hingga merah diinterpretasikan sebagai batuan lava dengan nilai resistivitas batuan diatas 2000 ohm meter. Batuan lava ini secara fisik berwarna kelabu gelap, kompak, material penyusun batuan terdiri atas mineral plagioklas, piroksen, amfibol. Batuan ini menunjukkan kemas tertutup dan porositas batuan jelek karena pada batuan ini porositas yang berkembang adalah porositas sekunder berupa patahan.

Pada lintasan $\mathrm{C}$ hasilnya setelah dikorelasikan dengan data geologi adalah tidak jauh berbeda dengan lintasan pertama. Dari peta penampang bawah permukaan dapat ditafsirkan bahwa dibawahnya terdapat berbagai batuan diantaranya batu tufa gunungapi, breksi vulkanik, aglomerat dan batuan lava (tabel resistivitas batuan oleh Suyono, 1978) .

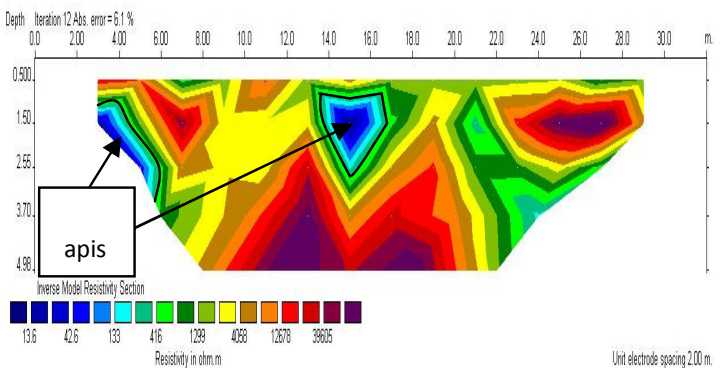

Gambar 4. Lapisan pembawa air panas pada lintasan C

Penampang anomali resistivitas yang menarik adalah warna biru (baik biru tua maupun biru cerah), akan tetapi karena panjang lintasan yang pendek sehingga kedalaman yang diperoleh juga dangkal menyebabkan hasil penelitian juga kurang maksimal. Pada lintasan $\mathrm{C}$ penampang anomali resistivitas yang diduga sebagai pembawa air panas yaitu lapisan yang di interpretasikan dengan warna biru baik biru tua maupun biru cerah. Lapisan dengan warna biru tua tersebut (resistivitas batuan sebesar 13,6 ohm meter) diinterpretasikan sebagai tufa gunungapi yang terlempungkan (tabel batuan oleh Suyono, 1978), dimana batuan ini dapat menyimpan air. Sedangkan warna biru dengan nilai resistivitas sebesar 42,6 ohm meter diduga merupakan tufa gunungapi (tabel resistivitas batuan oleh Suyono, 1978). Selanjutnya lapisan dengan warna biru agak cerah dan biru cerah dengan nilai resistivitas sebesar $133 \mathrm{ohm}$ meter diinterpretasikan sebagai aglomerat yang berada pada interval resistivitas 100-500 ohm meter (tabel resistivitas batuan oleh Suyono, 1978). Lapisan yang terakhir adalah warna biru kehijauan diinterpretasikan sebagai breksi vulkanik dengan resistivitas batuan sebesar $416 \mathrm{ohm}$ meter (tabel resistivitas batuan oleh Suyono, 1978).

Di dalam pembentukan sistem hydrothermal ada beberapa syarat tertentu yang harus terpenuhi seperti harus tersedianya air, batuan pemanas, atau sumber panas lainnya (misalnya panas yang ditimbulkan oleh pergerakan sesar aktif, dimana sumber panas ini tersebar di sepanjang bidang sesar), batuan sarang dan batuan penutup (cap rock). Pada 
hasil interpretasi yang diperoleh, tidak semua syarat tersebut terdeteksi. Pada lintasan B dan $\mathrm{C}$, yang terdeteksi sebagai lapisan pembawa air panas adalah lapisan yang tersusun atas tufa gunungapi dimana tufa gunungapi berukuran pasir halus hingga kerikil yang diduga merupakan batuan sarang. Lapisan ini diduga mampu membawa air panas karena memiliki porositas yang tidak terlalu jelek. Diluar lapisan ini terdeteksi adanya lapisan batuan aglomerat berukuran pasir kasar-bom. Lapisan ini diduga masih mampu membawa air. Lapisan selanjutnya adalah batuan breksi vulkanik yang diduga merupakan batuan sarang karena memiliki banyak rekahan dan sifat kesarangan batuan cukup baik serta diperkirakan memiliki sifat permeabel yang berfungsi menampung air yang telah terpanasi, sedangkan lapisan yang paling luar merupakan lapisan batuan lava yang memiliki porositas jelek atau porositas sekunder berupa patahan sehingga tidak bisa mengalirkan air jika tidak terdapat patahan pada lapisan batuan ini.

Pada gambar penampang bawah permukaan baik pada lintasan $\mathrm{B}$ maupun $\mathrm{C}$ terlihat bahwa lapisan air panas tersebut tidak kontinu antara yang satu dengan yang lain. Hal itu diduga karena adanya rekahan pada batuan penyusun bawah permukaan, sehingga air panas akan mengalir melalui rekahan-rekahan tersebut dan akan tertahan di satu tempat apabila pada lapisan tersebut mampu menyimpan air. Akan tetapi hal ini masih berupa dugaan karena penelitian ini masih merupakan penelitian pendahuluan, sehingga masih diperlukan serangkaian penelitian lagi untuk membuktikan kebenarannya.

Pada dasarnya sumber energi panas bumi berasal dari magma yang berada di dalam bumi. Magma tersebut menghantarkan panas secara konduktif pada batuan disekitarnya. Panas tersebut juga mengakibatkan aliran konveksi fluida hidrotherma1 di dalam pori-pori batuan. Kemudian fluida hidrothermal ini akan bergerak ke atas namun tidak sampai ke permukaan karena tertahan oleh lapisan batuan yang bersifat impermeabel. Dengan adanya lapisan impermeabel tersebut, maka hidrothermal yang terdapat pada reservoir panasbumi terpisah dengan groundwater yang berada lebih dangkal. Akan tetapi sampai dengan saat ini belum dapat diketahui secara pasti apakah air panas itu berasal dari pemanasan batuan dasar (berupa magma) dibawah titik sumber atau hanya merupakan aliran air panas dari daerah yang lain yang muncul ke permukaan akibat adanya rekahan pada batuan yang merupakan aliran air panas.

Berdasarkan penelitian sebelumnya oleh Bagus Priyambodo dengan menggunakan metode geolistrik di daerah Songgoriti Batu, arah akumulasi fluida panas menuju ke arah barat yang termasuk dalam rangkaian Cangar-Songgoriti-Kasinan (timur laut-barat daya).

\section{KESIMPULAN}

1. Metode geolistrik dapat dimanfaatkan untuk mendeteksi sebaran air panas melalui sifat kelistrikan batuan berdasarkan nilai tahanan jenis batuan.

2. Berdasarkan hasil interpretasi pada penampang lintasan B dan $\mathrm{C}$ terdeteksi sebaran air panas disekitar sumber tidak kontinu dan potensi air panas masih kecil. Diduga air panas yang muncul ke permukaan berasal dari aliran air panas dari arah songgoriti- 
cangar. Air panas tersebut muncul ke permukaan diduga karena adanya rekahan batuan di bawah permukaan.

3. Interpretasi geologi pada lintasan B dan C menunjukkan bahwa pada kedua lintasan tersebut didominasi oleh lapisan yang tidak memiliki sifat pembawa air panas yang berupa batuan lava dan campuran batuan lava dengan andesit yang menunjukkan kemas tertutup dan porositas batuan jelek. Diduga terbentuknya lapisan bawah permukaan akibat material letusan gunungapi pada masa lampau yang mengendap di daerah sumber air panas Kasinan.

\section{SARAN}

1. Pemodelan penampang bawah permukaan untuk survey air panas (hidrothermal) atau struktur bawah permukaan dapat dikembangkan dalam pemodelan secara tiga dimensi menggunakan software Res3dinv sehingga diperoleh gambaran aliran air panas yang lebih baik.

2. Sebaiknya dilakukan penelitian dengan menggunakan metode geofisika yang lain dan juga diperlukan serangkaian survey seperti survey geokimia, survey geologi dan survey hidrogeologi sehingga informasi yang diperoleh akan lebih akurat.

\section{DAFTAR PUSTAKA}

Anonymous.2011.http://geothermal.itb.ac.id/wpcontent/uploads/Sekilas_tentang_Panas_B umi. pdf. Diakses pada hari minggu tanggal 20 Februari 2011.

Anonymous.2011.http://pesanggrahanbatu.wordpress.com/about/. Diakses pada hari jumat tanggal 25 Februari 2011.

Bagus Priyambodo. 2004. Studi Zona Hidrothermal Songgoriti, Batu dengan Metode Geolistrik Tahanan Jenis Konfigurasi Wenner Sounding. Universitas Brawijaya. Tidak dipublikasikan

Burger, Henry Robert. 1992. Exploration Geophisics Of The Shallow Subsurface. New Jersey: Prentice Hall.

Firdaus, Djadjuli. 1984. Aplikasi Geolistrik Tahanan Jenis Untuk Eksplorasi Panas Bumi. Diktat Geologi Pertambangan dan Mineralogi,LIPI: Bandung

Irjan, dkk. 2010. Pemetaan Potensi Air Tanah (Aquifer) Berdasarkan Interpretasi Data Resistivitas Wenner sounding UIN MALIKI Malang. Laporan Penelitian tidak dipublikasikan.

Kurniati, Asih dkk. 2008. Buku Panduan Workshop Geofisika. Malang: Laboratorium Geofisika Jurusan Fisika Universitas Brawijaya.

Robinson \& Coruh. 1998. Basic Exploration Geophysic. John Willey and Son,Inc. Canada

Santoso, Djoko. 1995. Diktat Kuliah TG-424 Eksplorasi Energi Panas Bumi. Jurusan Teknik Geologi ITB: Bandung

Sosrodarsono, Suyono. 1993. Hidrologi Untuk Pengairan PT Pramadya Pramita Edisi Ketiga. Jakarta : Erlangga.

Telford, W.M. 1976. Applied Geophysic. Cambridge University Press: Cambridge 